\title{
STUDY OF EFFECTIVENESS OF SEWAGE TREATMENT IN MEDIUM SAND WITH A SUPPORTIVE SMALL COAL LAYER
}

\author{
Marek Kalenik \\ Institute of Environmental Engineering, Department of Hydraulic and Sanitary Engineering, Faculty of Civil and Environmental \\ Engineering, Warsaw University of Life Sciences - SGGW, ul. Nowoursynowska 159, 02-776 Warsaw
}

\begin{abstract}
Aim of the study

The aim of the study was to laboratory determine whether introducing a supportive small coal layer with a granulation of $0.02-5 \mathrm{~mm}$ will improve the effectiveness of removal of nitrogen and phosphorus compounds from domestic sewage. The study concerned a layer that improves effectiveness of domestic sewage treatment in a household sewage treatment plant under an infiltration drainage system.
\end{abstract}

\begin{abstract}
Material and methods
Sewage treatment model study was conducted in a medium sand bed with a supportive small coal layer with a thickness of 0.10 and $0.2 \mathrm{~m}$. Total suspended solids (TSS) were determined with a gravimetric method, $\mathrm{BOD}_{5}$ with an electrochemical method, COD with a titration method with potassium dichromate, ammonium nitrogen, nitrite nitrogen, nitrate nitrogen, total nitrogen and total phosphorus were determined using colorimetric methods, and the reaction with an electrometric method.
\end{abstract}

\begin{abstract}
Results and conclusions
It was observed that in terms of basic quality parameters (TSS, $\mathrm{BOD}_{5}, \mathrm{COD}$, total nitrogen, total phosphorus) the effectiveness of sewage treatment was compliant with Polish guidelines for sewage disposal into ground and groundwaters. It was determined that a soil bed consisting of medium sand with a supportive layer of small coal with a thickness of $0.20 \mathrm{~m}$ is more effective in sewage treatment in comparison to a supportive layer with a thickness of $0.10 \mathrm{~m}$. Application of the supportive layer of small coal with a thickness of $0.2 \mathrm{~m}$ in the medium sand soil bed improved the removal effectiveness of TSS by an average $19.8 \%$, of BOD $_{5}$ by $1.1 \%$, of COD by $4.7 \%$, of total nitrogen by $24.7 \%$, of ammonium nitrogen by $7.1 \%$ and of total phosphorus by $30.6 \%$ in comparison to the supportive layer with a thickness of $0.10 \mathrm{~m}$. The study confirmed that small coal with granulation of $0.02-5 \mathrm{~mm}$ can be used to support removal of nitrogen and phosphorus compounds from sewage with an infiltration drainage system.
\end{abstract}

Keywords: household sewage treatment plant, infiltration drainage, small coal

\section{INTRODUCTION}

Currently in Poland, rural communes are struggling with the problem of sewage management. Decades of neglect regarding sewage disposal and treatment have led to large disproportions between the water supply system and the construction of sewage systems. In towns with a high building density with developed infrastructure, domestic sewage is discharged into collective sewage systems. However, in towns with a dispersed building development, the most common method of domestic sewage disposal from residential

凶e-mail:marek_kalenik@sggw.pl 
and farm buildings is their collection in a drainless tank, with subsequent disposal by a gully emptier to a sewage treatment plant, sometimes to a field or a ditch. This type of sewage system is expensive in operation, and drainless tanks are often leaking and sometimes lack ventilation chimneys, that are necessary to remove gases formed during fermentation. Untreated sewage and sediments that enter the ground are a major sanitary threat due to the presence of pathogenic bacteria and parasite eggs.

Construction of systems for collection and treatment of domestic sewage in rural areas is in many cases impossible due to the dispersed building development, unfavourable topography of the area and high investment costs. Under these conditions, home sewage treatment plants with an infiltration drainage, in which a two-stage domestic sewage treatment sys- tem is used, i.e. mechanical and biological treatment, may be an alternative. Mechanical treatment of domestic sewage is carried out in a septic tank (2, see: Fig. 1) where sedimentation, flotation and fermentation processes occur. During these processes, mineral and organic impurities with a density greater than the liquid density (sand, faeces, paper) and the ones with a density lesser than the liquid density (fats) are removed from sewage. On the other hand, biological treatment of domestic sewage is carried out in a soil bed under an infiltration drainage (5, see: Fig. 1) where the processes of nitrification (nitrogen removal), adsorption and precipitation (phosphorus removal) take place. Then the treated sewage is discharged into the ground and groundwater. If a soil bed is moderately permeable, no filtration or straining supportive layers are used (see: Fig. 1c), whereas when a soil bed is

a)

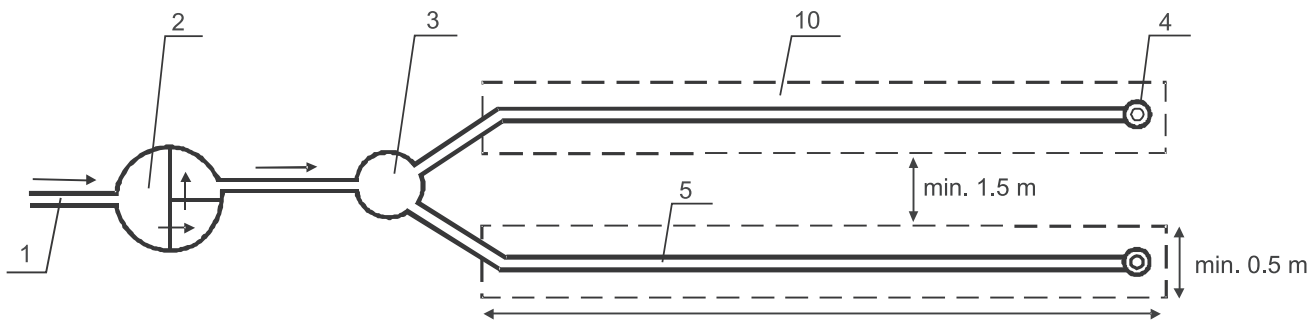

b)

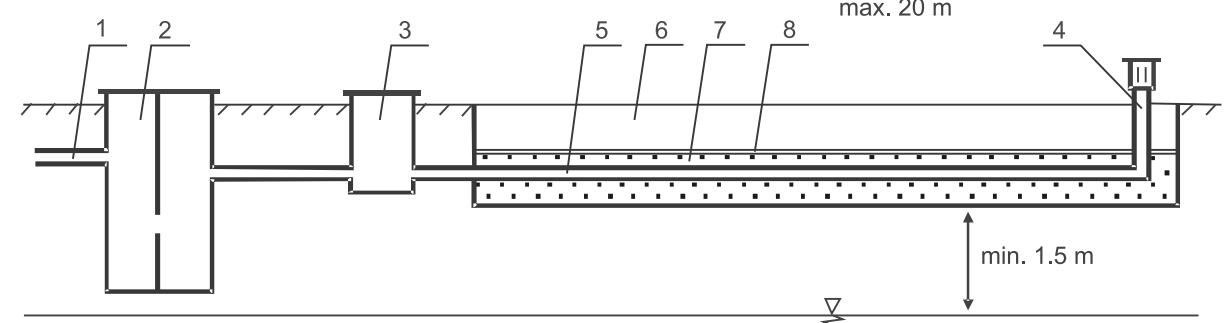

c)

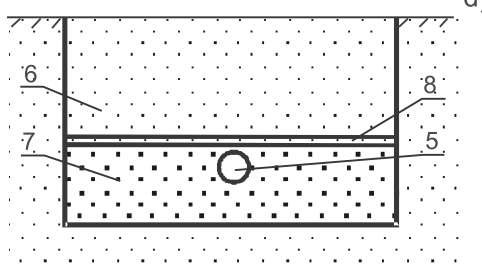

d)

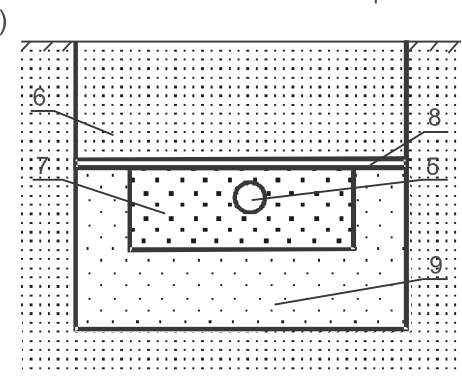

e)

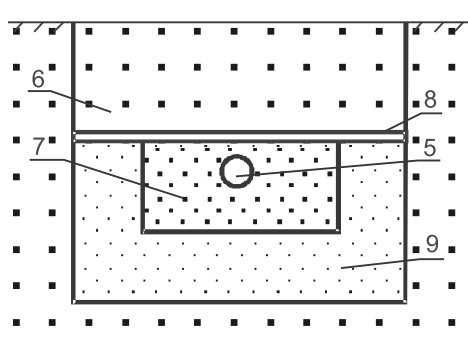

Fig. 1. Scheme of a sewage infiltration drainage: a) horizontal section, b) longitudinal section, c) cross-section of a drainage in moderately permeable ground, d) cross-section of a drainage in low-permeable soil, e) cross-section of a drainage in highly-permeable soil, 1 - sewage supply pipeline, 2 - septic tank, 3 - dispenser, 4 - ventilation pipes, 5 - sewage infiltrating pipeline, 6 - subsoil, 7 - sewage infiltration bed, 8 - geotextile, 9 - supportive layer, 10 - sewage infiltration layer 
low-permeable, a filtration supportive layer (see: Fig. 1d) is used, and when a soil bed is highly-permeable, a straining supportive layer (see: Fig. 1e) is used. A layer that supports filtration or straining is usually made of medium sand with a thickness of $0.3 \mathrm{~m}$ (Małe oczyszczalnie ścieków, 1990).

A mound septic system is a specific solution for household sewage treatment plants with an infiltration drainage, and it is constructed in embankments (see: Fig. 2). This solution is used in permeable grounds with a high groundwater table. In a household sewage treatment plant with a mound septic system, sewage after a septic tank may be pumped into a dispenser with a standard pump (10, see: Fig. 2) or with an airlift pump (Kalenik, 2015; Kalenik, 2017; Kalenik and Chalecki, 2018; Kalenik and Malarski, 2018; Kujawiak et al., 2018). In this solution, the use of an airlift pump significantly improves the effectiveness of sewage treatment in the soil bed under the infiltration drainage as sewage is intensively oxygenated during its transport through the pressure pipeline (11, see: Fig. 2) to the dispenser (Kalenik, 2014b).

Household sewage treatment plants with an infiltration drainage to treat household sewage to be introduced into the ground after pre-treatment can be built outside an agglomeration within a land owned by the introducer, if the following conditions are met (Rozporządzenie Ministra Gospodarki Morskiej i Żeglugi Śródlądowej, 2019):

- the amount of sewage does not exceed $5 \mathrm{~m}^{3}$ per day,

- the $\mathrm{BOD}_{5}$ of sewage inflowing into the infiltration drainage or mound septic system is reduced by $20 \%$ and the content TSS by $50 \%$,
- the distance of underground waters from the level where sewage infiltration of pre-treated sewage occurs may not be lesser than $1.5 \mathrm{~m}$ from the highest useful groundwater aquifer.

Also, the plot area must be large enough to enable maintaining adequate distances from a septic tank to a house $-5 \mathrm{~m}$, to a plot border $-2 \mathrm{~m}$, to a well $-15 \mathrm{~m}$ and from a sewage infiltration drainage to a well $30 \mathrm{~m}$, to a tree $-3 \mathrm{~m}$ (Rozporządzenie Ministra Infrastruktury, 2002). According to The Construction Law (1994), construction of a household sewage treatment plant does not require a construction permit but only notifying the architectural and construction administration body.

In this type of household sewage treatment plants, overloading of the soil bed with suspensions and colloids leads to the formation of a so-called filter cake (Spychała and Nieć, 2013, Mazur et al., 2016) on the ground surface and in its pores, and a decrease in ground permeability (Nieć and Spychała, 2014). TSS content in raw sewage outflowing from a septic tank into the soil bed may vary from $20 \mathrm{~g} \times \mathrm{m}^{-3}$ to as much

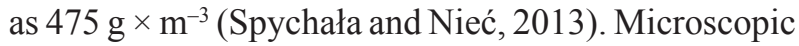
analyses have shown that the filter cake formed in the ground contains mainly threadlike toilet paper fibres that are washed out of the septic tank, and their biodegradation rate is much slower than their rate of accumulation in the ground (Spychała and Nieć, 2013).

The conducted studies (Hawkins et al., 2008) have shown that earthworms that aerate the soil (they create vertical and horizontal burrows) are eager to live in the bed ground located under the infiltration drainage, which improves the bed's permeability. Introducing earthworms into a clogged soil bed under an infiltra-

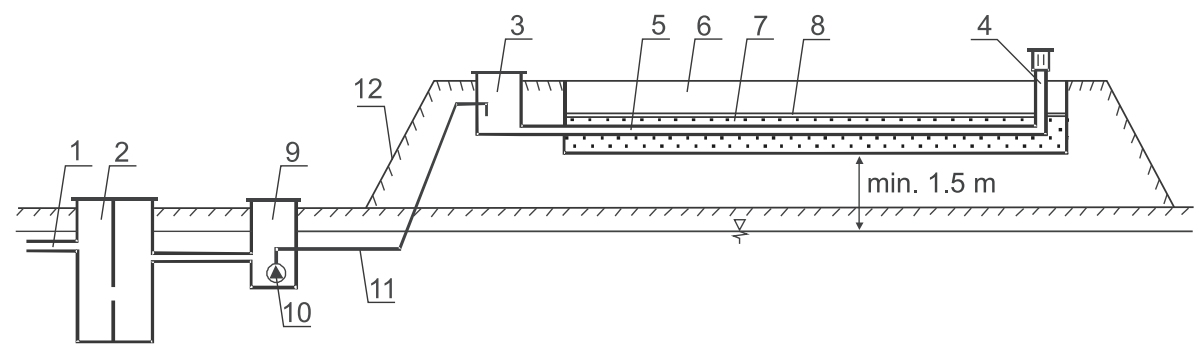

Fig. 2. Scheme of a mound septic system: 1 - sewage supply pipeline, 2 - septic tank, 3 - dispenser, 4 - ventilation pipes, 5 - sewage infiltration pipeline, 6 - subsoil, 7 - sewage infiltration bed, 8 - geotextile, 9 - sump , 10 - pump, 11 - pressure pipeline, 12 - ground embankment (mound) 
tion drainage improves its permeability and reduces the content of organic substance in the bed in two weeks (Spychała and Pilc, 2011).

The research conducted on a bed ground consisting of medium sand shows that the average effectiveness of total nitrogen $(22 \%)$ and total phosphorus $(23 \%)$ removal was low (Kalenik and Wancerz, 2013). Other researchers confirmed in their studies (Gill et al., 2009; Sieczka and Koda, 2016a) that the effectiveness of nitrogen and phosphorus removal from sewage by highly-permeable ground is low. A large number of household sewage treatment plants with infiltration drainage in a given area may lead to contamination of groundwaters with nitrogen and phosphorus compounds (Heatwole and Mccray, 2007; Sieczka and Koda, 2016b; Radziemska et al., 2017; Koda et al., 2017; Eveborn et al., 2012). On the other hand, phosphorus compounds cumulated in ground bed under an infiltration drainage may be successfully used by plants (Kvarnström et al., 2004). The following fungi may be used to improve the effectiveness of nitrogen and phosphorus removal in bed grounds located under infiltration drainages: Trichothecium roseum for removing phosphates (effectiveness - 97.5\%), and Epicoccum nigrum, Geotrichum candidum and Trichoderma for removing ammonium nitrogen (effectiveness $-84 \%$ ), total nitrogen (effectiveness $-86.8 \%$ ) and for eliminating faecal type coliform bacteria (effectiveness $-20 \div 38 \%$ ) (Kołwzan et al., 2018). Fungal strains may be introduced into the sewage infiltration layer and the soil bed where they will develop and purify the sewage introduced into the ground.

In order to improve the effectiveness of sewage purification in a highly-permeable soil bed, a research was conducted on application of following supportive layers: dolomite (Kalenik and Cieśluk, 2009), chalcedonite (Kalenik and Wancerz, 2013), clinoptilolite (Kalenik, 2014a; Kalenik and Chalecki, 2019), kermesite and gaize (Dacewicz, 2018), hydro-anthracite (Kalenik, 2019). On the other hand, there is no research regarding the use of small coal for treating sewage in soil beds in scientific and technical literature. Relatedly, the aim of the study was to laboratory determine whether introducing a supportive small coal layer with a granulation of $0.02-5 \mathrm{~mm}$ will improve the effectiveness of removal of nitrogen and phosphorus compounds from sewage. For this purpose, mod- el medium sand soil beds with small coal layers (see: Fig. 3) with thicknesses of $0.10 \mathrm{~m}$ and $0.20 \mathrm{~m}$ located under the sewage infiltration drainage were used.

Small coal was used for the research as it is characterised by very strong binding properties of adsorbed substances on its surface, it has a significant specific surface area resulting from the large proportion of very small pores, it is abrasion-resistant and neutral to the environment (see: Fig. 3). Relatedly, a hypothesis that small coal is highly-adsorbent and it will immobilise bacteria that will take part in the aerobic sewage treatment process on coals grains was taken.

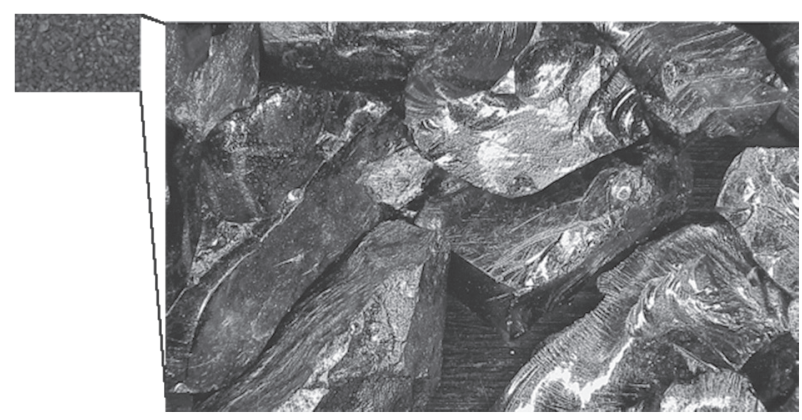

Fig. 3. Image of the surface of small coal taken with the HIROX RH-2000 digital microscope - 15 times magnified

\section{DESCRIPTION OF TEST STATION AND RESEARCH METHOD}

A test station in the form of an airtight, $1.20 \mathrm{~m}$ long, $0.20 \mathrm{~m}$ wide and $1.70 \mathrm{~m}$ tall tank was constructed in order to test the sewage treatment effectiveness (see: Fig. 4). The tank was made of plastic boards (9) mounted in a metal frame (11). Sewage from the tank (1) was passed through a pipeline (4) by a pump (2), activated with a driver (3), into infiltration pipeline with a diameter of $100 \mathrm{~mm}(5)$ that was located in a bed layer (6) made of stones with a diameter of $20 \div 40 \mathrm{~mm}$. Dimensions of the infiltration bed layer are: length $0.50 \mathrm{~m}$, width $0.20 \mathrm{~m}$, height $0.20 \mathrm{~m}$. Sewage was flowing into the bed layer through an inlet with a diameter of $8 \mathrm{~mm}$ located on the bottom of the infiltration pipeline. After flowing through the infiltration layer, the sewage was flowing through the supportive layer (7) into the soil bed (8). Ventilation of the infiltration bed (6) occurred through the infiltration pipeline (5). 


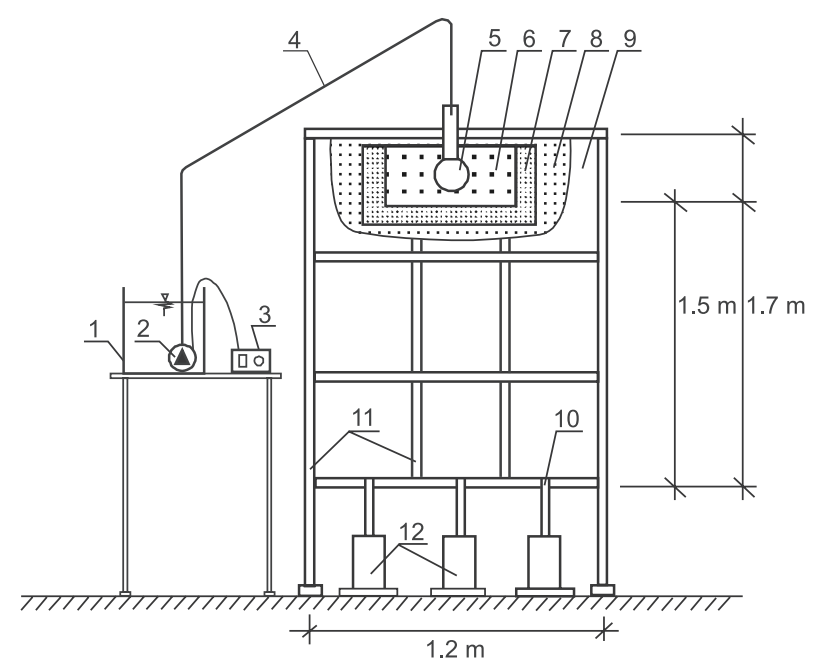

Fig. 4. Test station scheme: 1 - tank, 2 - pump, 3 - driver, 4 - pipeline, 5 - infiltration pipeline, 6 - infiltration bed, 7 - supportive layer (small coal), 8 - soil bed (medium sand), 9 - transparent plastic board, 10 - sewage outflow, 11 - metal frame, 12 - vessels collecting filtered sewage

The research was conducted with the use of a medium sand soil bed with a supportive layer consisting of small coal with a thickness of $0.10 \mathrm{~m}$ or $0.20 \mathrm{~m}$ and with a granulation of $0.02-5.0 \mathrm{~mm}$. Thickness of the sand soil bed was $1.4 \mathrm{~m}$ and $1.3 \mathrm{~m}$, respectively. Three outflow holes (10) were made in the bottom of the test station. They enabled the outflow of the sewage that flowed through the supportive layer and the soil bed into the vessels (12). The tank was filled with ground in the form of layers with a thickness of $0.10 \mathrm{~m}$ which were then thickened by compacting (ground density was not defined). The best effects of compacting sandy soils are obtained by compacting them in layers (Tymosiak and Sulewska, 2016).

Contents of specific soil granulation fractions were determined with the sieve analysis method. Granulometric tests of three samples of medium sand and small coal were conducted and their results are presented in Figures 5 and 6. With the carried out tracing tests, it was determined that the time of filtration of sewage through the sand soil bed with the supportive layer of small coal was 17 hours.

Knowing the type of soil (medium sand), the daily dose of sewage was determined, referring it to the length of the infiltration pipeline (in accordance with Polish recommendations). Hydraulic load of an infiltration pipeline according to guidelines (Centralny Urząd Gospodarki Wodnej, 1971) refers to a $1 \mathrm{~m}$ long pipeline, and in the case of medium sand it is $15 \mathrm{dm}^{3} \cdot \mathrm{m}^{-1} \cdot \mathrm{d}^{-1}$. Relatedly, the daily sewage dose is $3 \mathrm{dm}^{3} \cdot \mathrm{d}^{-1}$. In the test station (see: Fig. 4), sewage was introduced into the infiltration pipeline (5) at $8 \mathrm{am}$, $4 \mathrm{pm}$ and $12 \mathrm{pm}$ in the amount of $1 \mathrm{dm}^{3}$.

Model sewage was used for the research purposes, and it was prepared accordingly to the norm (PN-C-04616/10, 1987) on distilled water from the following components: dehydrated enriched broth $150 \mathrm{~g} \cdot \mathrm{m}^{-3}$, peptone $-50 \mathrm{~g} \cdot \mathrm{m}^{-3}$, urea $-30 \mathrm{~g} \cdot \mathrm{m}^{-3}$, anhydrous sodium acetate $-10 \mathrm{~g} \cdot \mathrm{m}^{-3}$, soluble starch $50 \mathrm{~g} \cdot \mathrm{m}^{-3}$, grey soap $-50 \mathrm{~g} \cdot \mathrm{m}^{-3}$, crystalline calcium chloride $-7 \mathrm{~g} \cdot \mathrm{m}^{-3}$, magnesium sulphate $-50 \mathrm{~g} \cdot \mathrm{m}^{-3}$, sodium chloride $-30 \mathrm{~g} \cdot \mathrm{m}^{-3}$, potassium chloride $7 \mathrm{~g} \cdot \mathrm{m}^{-3}$. The sewage was analysed physically and chemically before and after infiltration through the soil bed with the supportive layer in order to determine values of the following indicators: TSS, $\mathrm{BOD}_{5}$, $\mathrm{COD}$, total nitrogen, total phosphorus, ammonium nitrogen, nitrate nitrogen, nitrite nitrogen and reaction. Determination of specific values was performed weekly, taking into account the time of sewage filtration through the soil bed with the supportive layer with thickness of $0.10 \mathrm{~m}$ or $0.20 \mathrm{~m}$.

Model sewage was prepared every six days, and sewage quality indicators were determined on the first, third and sixth day from its dosing. The temperature in the laboratory during the research was stable and it was $14^{\circ} \mathrm{C}$. Total suspended solids (TSS) were determined with a gravimetric method, $\mathrm{BOD}_{5}$ with an electrochemical method, COD with a titration method with potassium dichromate, ammonium nitrogen, nitrite nitrogen, nitrate nitrogen as well as total nitrogen and total phosphorus were determined using colorimetric methods and the reaction by a electrometric method. 


\section{DISCUSSION OF RESULTS}

The test station (see: Fig. 4) was constructed in accordance with the Regulation (Rozporządzenie..., 2019) and a $1.5 \mathrm{~m}$ deep layer was preserved between the sewage infiltration level and the highest useful groundwater aquifer (in the test station it is the purified sewage retrieval level) In the analysed experiment, the effectiveness of the total nitrogen and total phosphorus removal in the soil bed made of sand was not studied, as it is known to be poor from literature (Van Cuyk et al., 2001; Gill et al., 2009; Kalenik and Wancerz, 2013). However, this type of study was performed in 2013 for medium sand alone (see: Fig. 5), and its results (see: Table 1) were published in the work by Kalenik and Wancerz (2013).

It took seven weeks for the medium sand soil bed with the small coal layer to achieve readiness. The time was defined based on control determination tests for total nitrogen and total phosphorus only. In the sixth and seventh week, control determination tests for total nitrogen and total phosphorus were performed in order to check whether nitrogen and phosphorus compounds were already being removed, and whether their values were comparable (stable). During the filtration of sewage through the tested soil beds located under the sewage infiltration layer, soil with a depth of $2.0 \div 2.5$ $\mathrm{cm}$ changed its colour from light to dark, what indi- cates the formation of a biological membrane that was the growth medium for bacteria and other microorganisms. The process is known and described in literature (Laak, 1986; Canter and Knox, 1991; Van Cuyk et al., 2001; Beal et al., 2005). During the research, the soil bed (medium sand) was saturated with sewage (it was wet) but sewage did not stagnate in the soil bed during the filtration.

Table 2 summarises the average values of indicators for the pollution of untreated and treated sewage on medium sand soil beds with a supportive layer of small coal of two thicknesses $-0.10 \mathrm{~m}$ and $0.20 \mathrm{~m}$, depending on the working time of the test station. Analysing the test results, it can be concluded that after the infiltration of model sewage through the sandy soil bed with the small coal supportive layer, the content of TSS decreased, and so did the values of $\mathrm{BOD}_{5}, \mathrm{COD}$, total nitrogen, ammonium nitrogen and total phosphorus. Nitrite nitrogen occurred in trace amounts but on the other hand the content of nitrates and the $\mathrm{pH}$ value increased.

In the soil bed with a small coal layer with a thickness of $0.10 \mathrm{~m}$, the effectiveness of TSS removal was $51.3 \%$, and in the bed with the $0.20 \mathrm{~m}$ thick layer $71.1 \%$. In the bed with the medium sand layer alone the effectiveness of TSS removal was also high and amounted for $80.2 \%$ (Kalenik and Wancerz, 2013). What attracts attention is the fact that the studied soil bed is highly effective in terms of TSS retention. Large

Table 1. Results of the studies of raw and purified sewage for medium sand (average values) (Kalenik and Wancerz, 2013)

\begin{tabular}{|c|c|c|c|c|c|}
\hline \multirow[b]{2}{*}{ Indicator, unit } & \multirow[b]{2}{*}{ Raw sewage } & \multicolumn{3}{|c|}{ Purified sewage } & \multirow[b]{2}{*}{ Regulation, 2019} \\
\hline & & $\begin{array}{c}13 \\
\text { week }\end{array}$ & $\begin{array}{c}14 \\
\text { week }\end{array}$ & $\begin{array}{c}15 \\
\text { week }\end{array}$ & \\
\hline $\mathrm{TSS}, \mathrm{g} \cdot \mathrm{m}^{-3}$ & 64 & 16 & 10 & 12 & 50 \\
\hline $\mathrm{BOD}_{5}, \mathrm{gO}_{2} \cdot \mathrm{m}^{-3}$ & 153 & 2.2 & 5 & 3 & 40 \\
\hline $\mathrm{COD}, \mathrm{gO}_{2} \cdot \mathrm{m}^{-3}$ & 209.39 & 23.13 & 28.13 & 25.92 & 150 \\
\hline Total nitrogen, $\mathrm{gN} \cdot \mathrm{m}^{-3}$ & 16.33 & 15 & 14 & 9 & 30 \\
\hline Ammonium nitrogen, $\mathrm{gN}-\mathrm{NH}_{4} \cdot \mathrm{m}^{-3}$ & 6.4 & 0.03 & 0.035 & 0.03 & - \\
\hline Nitrate nitrogen, $\mathrm{gN}^{-\mathrm{NO}_{3}} \cdot \mathrm{m}^{-3}$ & 0.62 & 94.15 & 92.12 & 89.67 & - \\
\hline Nitrite nitrogen, $\mathrm{gN}-\mathrm{NO}_{2} \cdot \mathrm{m}^{-3}$ & 0.014 & 0.007 & 0.004 & 0.006 & - \\
\hline Total phosphorus, $\mathrm{gP} \cdot \mathrm{m}^{-3}$ & 2.95 & 2.58 & 2.17 & 2.07 & 5 \\
\hline Reaction, pH & 6.6 & 7.25 & 7.2 & 7.17 & - \\
\hline
\end{tabular}


number of TSS introduced into the soil bed causes its quick colmatation which leads to the formation of a filter cake under the infiltration drainage (Spychała and Nieć, 2013; Mazur et al., 2016) which reduces the soil bed permeability and thus reduces the life-span of a sewage treatment plant with an infiltration drainage.
A characteristic symptom of soil bed colmatation is the leakage of odours through ventilation chimneys of drains. It proves that the bed permeability decreased drastically, and sewage stagnates in the infiltration bed and oxygen does not reach its interior. Therefore, the conditions in the infiltration bed become anaerobic,

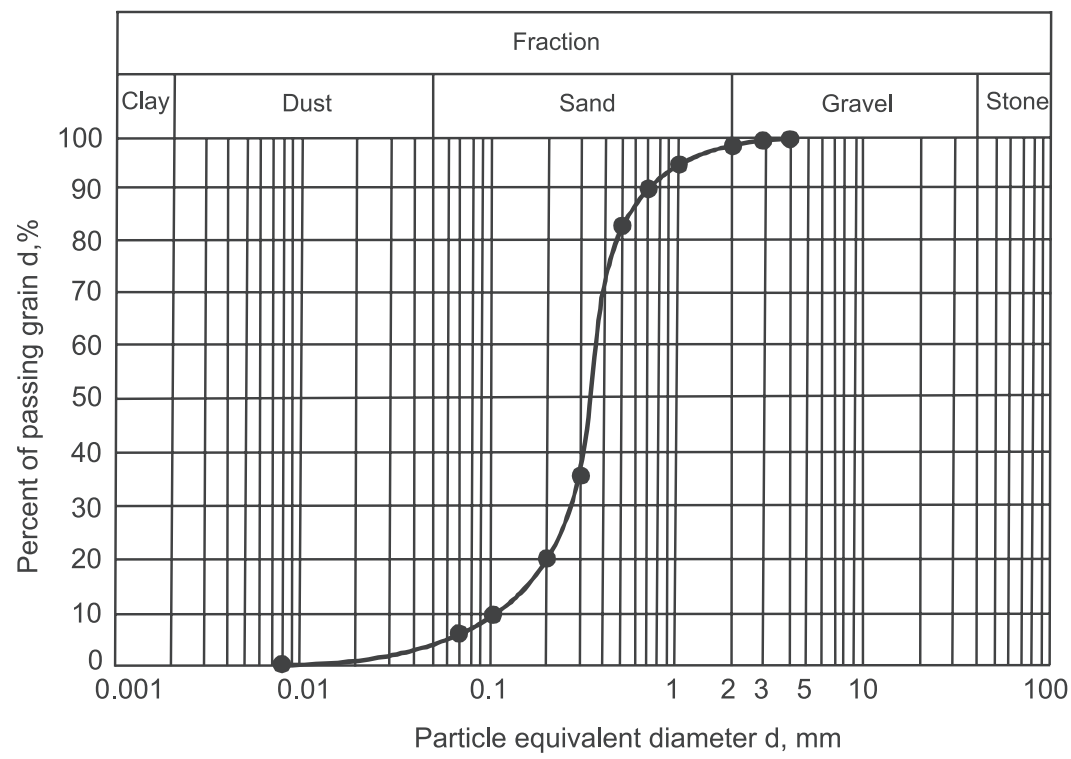

Fig. 5. Soil granulation curve - medium sand

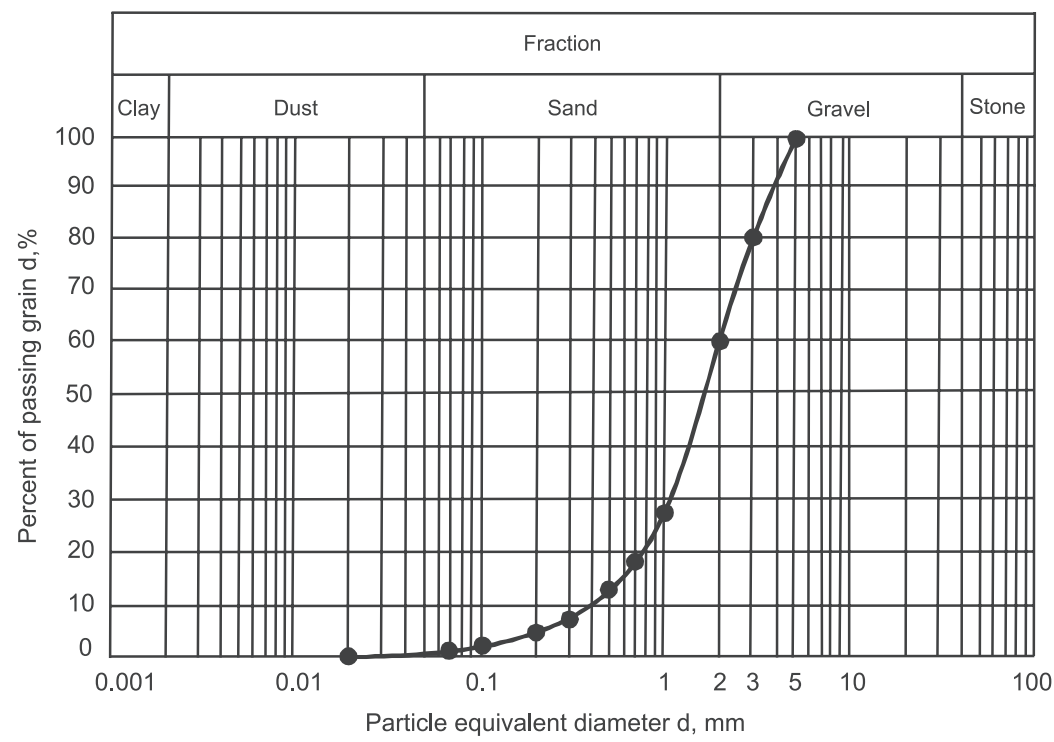

Fig. 6. Small coal granulation curve - coarse 
Kalenik, M. (2019). Study of effectiveness of sewage treatment in medium sand with a supportive small coal layer. Acta Sci. Pol., Formatio Circumiectus, 18 (3), 57-70. DOI: http://dx.doi.org/10.15576/ASP.FC/2019.18.3.57

and the rotting sewage emits odour. In this study, sewage did not stagnate in the infiltration bed and there was no odour coming from the infiltration bed.

Also in highly-permeable soil beds with a supportive layer made of dolomite (Kalenik and Cieśluk, 2009), chalcedonite (Kalenik and Wancerz, 2013), clinoptilolite (Kalenik, 2014a; Kalenik and Chalecki, 2019), and hydro-anthracite (Kalenik, 2019) the effectiveness of TSS retention was high and equalled $98.2 \%$ and $99.1 \%$ for dolomite, $94 \%$ for chalcedonite, $81.9 \%$ and $85.4 \%$ (2014a) and $72.5 \%$ and $75.8 \%$ (2019) for clinoptilolite, $77.1 \%$ and $80.2 \%$ for hydro-anthracite.

Average effectiveness of $\mathrm{BOD}_{5}$ and $\mathrm{COD}$ value reduction in sewage was high and it equalled $98.7 \%$ and $90.4 \%$, respectively, in the soil bed with the small coal layer with a thickness of $0.10 \mathrm{~m}$, and in the bed with the $0.2 \mathrm{~m}$ thick layer $-99.8 \%$ and 95 , respectively. In the bed with the medium sand layer alone, the effectiveness of $\mathrm{BOD}_{5}$ and $\mathrm{COD}$ value reduction was also high and equalled $97.8 \%$ and $87.7 \%$ (Kalenik and Wancerz, 2013), respectively. Laboratory research by Chmielowski and Ślizowski (2008) also confirmed the effectiveness of $\mathrm{BOD}_{5}$ and $\mathrm{COD}$ value reduction in sewage treated by highly-permeable soil, and it equalled $97.9 \%$ for $\mathrm{BOD}_{5}$, and $85.2 \%$ for COD.

On average, the effectiveness of total nitrogen removal in soil bed with the small coal layer with a thickness of $0.10 \mathrm{~m}$ equalled $31.9 \%$, and $56.6 \%$ for the $0.20 \mathrm{~m}$ thick layer. In the bed with the medium sand layer alone the effectiveness of total nitro-

Table 2. Characteristic of the sewage quality before and after the treatment in medium sand with the small coal supportive layer (average values)

\begin{tabular}{|c|c|c|c|c|c|c|c|c|c|}
\hline \multirow{2}{*}{ Indicator, unit } & \multicolumn{4}{|c|}{ Raw sewage } & \multicolumn{4}{|c|}{ Purified sewage } & \multirow{2}{*}{$\begin{array}{c}\text { Regulation } \\
2019\end{array}$} \\
\hline & 8 week & 9 week & 10 week & 11 week & 8 week & 9 week & 10 week & 11 week & \\
\hline \multicolumn{10}{|c|}{ Supportive layer consisting of small coal; thickness of $0.10 \mathrm{~m}$} \\
\hline TSS, $g \cdot \mathrm{m}^{-3}$ & 77.9 & 77.6 & 78.1 & 77.4 & 38.1 & 37.8 & 37.6 & 38.0 & 50 \\
\hline $\mathrm{BOD}_{5}, \mathrm{gO}_{2} \cdot \mathrm{m}^{-3}$ & 291.3 & 295.5 & 299.1 & 298.2 & 3.8 & 3.9 & 3.6 & 3.7 & 40 \\
\hline $\mathrm{COD}, \mathrm{gO}_{2} \cdot \mathrm{m}^{-3}$ & 386.6 & 393.1 & 382.9 & 395.0 & 37.7 & 38.1 & 36.9 & 37.4 & 150 \\
\hline Total nitrogen, $\mathrm{gN} \cdot \mathrm{m}^{-3}$ & 34.4 & 34.8 & 34.6 & 34.7 & 23.6 & 23.4 & 23.8 & 23.5 & 30 \\
\hline Ammonium nitrogen, $\mathrm{gN}_{-} \mathrm{NH}_{4} \cdot \mathrm{m}^{-3}$ & 1.87 & 1.89 & 1.90 & 1.92 & 0.23 & 0.22 & 0.24 & 0.22 & - \\
\hline Nitrate nitrogen, $\mathrm{gN}^{-\mathrm{NO}_{3}} \cdot \mathrm{m}^{-3}$ & 1.75 & 1.73 & 1.69 & 1.73 & 16.95 & 17.02 & 16.85 & 16.93 & - \\
\hline Nitrite nitrogen, $\mathrm{gN}^{-\mathrm{NO}_{2}} \cdot \mathrm{m}^{-3}$ & 0.045 & 0.047 & 0.048 & 0.044 & 0.008 & 0.006 & 0.007 & 0.006 & - \\
\hline Total phosphorus, $\mathrm{gP} \cdot \mathrm{m}^{-3}$ & 5.06 & 4.96 & 5.07 & 5.04 & 2.61 & 2.58 & 2.64 & 2.54 & 5 \\
\hline Reaction, $\mathrm{pH}$ & 7.44 & 7.45 & 7.49 & 7.43 & 7.71 & 7.63 & 7.70 & 7.67 & - \\
\hline \multicolumn{10}{|c|}{ Supportive layer consisting of small coal; thickness of $0.20 \mathrm{~m}$} \\
\hline TSS, $g \cdot \mathrm{m}^{-3}$ & 77.6 & 78.2 & 77.5 & 77.8 & 17.5 & 18.1 & 17.7 & 17.9 & 50 \\
\hline $\mathrm{BOD}_{5}, \mathrm{gO}_{2} \cdot \mathrm{m}^{-3}$ & 294.6 & 297.2 & 298.4 & 290.1 & 1.3 & 1.2 & 1.1 & 1.3 & 40 \\
\hline $\mathrm{COD}, \mathrm{gO}_{2} \cdot \mathrm{m}^{-3}$ & 392.1 & 389.7 & 385.9 & 390.3 & 17.3 & 16.9 & 17.5 & 16.8 & 150 \\
\hline Total nitrogen, $\mathrm{gN} \cdot \mathrm{m}^{-3}$ & 34.7 & 34.5 & 34.7 & 34.5 & 15.3 & 14.8 & 15.1 & 14.9 & 30 \\
\hline Ammonium nitrogen, $\mathrm{gN}^{-\mathrm{NH}_{4}} \cdot \mathrm{m}^{-3}$ & 1.93 & 1.87 & 1.91 & 1.88 & 0.09 & 0.11 & 0.10 & 0.09 & - \\
\hline Nitrate nitrogen, $\mathrm{gN}-\mathrm{NO}_{3} \cdot \mathrm{m}^{-3}$ & 1.68 & 1.70 & 1.71 & 1.72 & 12.03 & 11.89 & 11.87 & 11.94 & - \\
\hline Nitrite nitrogen, $\mathrm{gN}-\mathrm{NO}_{2} \cdot \mathrm{m}^{-3}$ & 0.047 & 0.043 & 0.047 & 0.049 & 0.003 & 0.004 & 0.002 & 0.003 & - \\
\hline Total phosphorus, $\mathrm{gP} \cdot \mathrm{m}^{-3}$ & 4.99 & 5.02 & 5.01 & 5.04 & 1.03 & 1.04 & 1.08 & 1.05 & 5 \\
\hline Reaction, $\mathrm{pH}$ & 7.94 & 7.93 & 7.90 & 8.02 & 8.21 & 8.14 & 8.19 & 8.23 & - \\
\hline
\end{tabular}


gen removal was low and equalled for $22 \%$ (Kalenik and Wancerz, 2013) on average. Thus, the use of the supportive small coal layer significantly increased the total nitrogen removal effectiveness from sewage. Also in highly-permeable soil beds with a supportive layer made of dolomite (Kalenik and Cieśluk, 2009), chalcedonite (Kalenik and Wancerz, 2013), clinoptilolite (Kalenik, 2014a; Kalenik and Chalecki, 2019), hydro-anthracite (Kalenik, 2019) the effectiveness of total nitrogen removal from sewage increased significantly and equalled $35 \%$ and $44 \%$ for dolomite, $66.8 \%$ for chalcedonite, $29.5 \%$ and $37.3 \%$ (2014a) and $26 \%$ and $55.3 \%$ (2019) for clinoptilolite, $28.4 \%$ and $57.8 \%$ for hydro-anthracite.

The effectiveness of ammonium nitrogen removal in the bed with the small coal layer with a thickness of $0.10 \mathrm{~m}$ equalled $87.8 \%$, and the nitrate nitrogen content in treated sewage increased 10 -fold on average. In the bed with the layer with a thickness of $0.20 \mathrm{~m}$ the effectiveness of ammonium nitrogen removal was even higher and equalled $94.9 \%$, and the nitrate nitrogen content in treated sewage increased only 7 -fold on average. In the bed with the medium sand layer alone the effectiveness of ammonium nitrogen removal was also high and equalled for $99 \%$ (Kalenik and Wancerz, 2013) on average. Also in highly-permeable soil beds with a supportive layer made of dolomite (Kalenik and Cieśluk, 2009), chalcedonite (Kalenik and Wancerz, 2013), clinoptilolite (Kalenik, 2014a; Kalenik and Chalecki, 2019) and hydro-anthracite (Kalenik, 2019) the effectiveness of ammonium nitrogen removal was high and equalled $98.2 \%$ and $99.1 \%$ for dolomite, $94 \%$ for chalcedonite, $81.9 \%$ and $85.4 \%$ (2014a) and $72.5 \%$ and $75.8 \%$ (2019) for clinoptilolite, $77.1 \%$ and $80.2 \%$ for hydro-anthracite. Also, Wasik and Chmielowski's (2017) research confirm high effectiveness of ammonium nitrogen removal in highly-permeable beds, and it equalled $66.74 \%$.

High content of nitrate nitrogen in treated sewage in the tested soil beds proves that there are very good nitrification conditions indicating that nitrifying bacteria immobilise well on small coal. On the other hand, according to Van Cuyk et al. (2001) and Gill et al. (2009), nitrification occurs very poorly on sand-only beds. Sand grains are made of quartz. Microscopic studies show that the surface of sand grains is not porous and is highly-polished. Also in the treated sewage (for both tested soil beds) the $\mathrm{pH}$ value increased by ca. $3.0 \%$ on average.

Phosphorus in a soil bed is removed mainly in adsorption and precipitation processes, and it is also retrieved by plants. The effectiveness of adsorption and precipitation processes depends both on the potential and the value of the redox reaction as well as the presence of iron, aluminium and calcium ions in the soil bed, as well as on the content of native phosphorus in the bed and its sorption capacity. In soil beds, the reaction of which is slightly acidic or neutral, the dominant role in adsorption processes is attributed to iron and aluminium compounds, which adsorb phosphorus in the form of insoluble complex compounds, causing its long-term retention. In soil beds which are alkaline, phosphorus adsorption processes occur due to calcium compounds, as they form permanent mineral connections with them. Studies show that in the soil bed with a small coal layer with a thickness of $0.10 \mathrm{~m}$ the effectiveness of total phosphorus removal was $48.5 \%$, and $79.1 \%$ in the bed with the $0.20 \mathrm{~m}$ thick layer. On the other hand, in the bed with the medium sand layer alone the effectiveness of total phosphorus removal was low and equalled for 23\% (Kalenik and Wancerz, 2013) on average. Thus, the use of the supportive small coal layer significantly increased the total phosphorus removal effectiveness from sewage. Also in highly-permeable soil beds with a supportive layer made of dolomite (Kalenik and Cieśluk, 2009), chalcedonite (Kalenik and Wancerz, 2013), clinoptilolite (Kalenik, 2014a; Kalenik and Chalecki, 2019), hydro-anthracite (Kalenik, 2019), the effectiveness of total phosphorus removal from sewage increased significantly and equalled $37 \%$ and $63 \%$ for dolomite, $43 \%$ for chalcedonite, $53.1 \%$ and $89.2 \%$ (2014a) and $56.5 \%$ and $82.4 \%$ (2019) for clinoptilolite, $52.3 \%$ and $75.3 \%$ for hydro-anthracite.

Table 3 compares the effectiveness of pollution removal in a bed with sand only and in sand beds with a supportive small coal layer with a thickness of $0.1 \mathrm{~m}$ and of $0.2 \mathrm{~m}$.

The performed tests (see: Table 2) show that the effectiveness of sewage treatment in a soil bed with a supportive layer of small coal meets Polish requirements for the introduction of wastewater into soil and groundwater (Rozporządzenie..., 2019). The results of studying the effectiveness of sewage purification in a soil bed 
Kalenik, M. (2019). Study of effectiveness of sewage treatment in medium sand with a supportive small coal layer. Acta Sci. Pol., Formatio Circumiectus, 18 (3), 57-70. DOI: http://dx.doi.org/10.15576/ASP.FC/2019.18.3.57

with a supportive small coal layer are comparable with earlier tests with following supportive layers: dolomite (Kalenik and Cieśluk, 2009), chalcedonite (Kalenik and Wancerz, 2013), clinoptilolite (Kalenik, 2014a; Kalenik and Chalecki, 2019), kermesite and gaize (Dacewicz, 2018), hydro-anthracite (Kalenik, 2019).

Also, a statistical analysis was performed in order to check whether average values concerning the effectiveness of sewage pollution removal for supportive small coal layers with a thickness of $0.10 \mathrm{~m}$ and $0.2 \mathrm{~m}$ (Table 2) are statistically significant. First, the normality of distribution was checked with the Shapiro-Wilk test, and then the homogeneity of variance with the Levene test. Calculations of normality of distributions and homogeneity of variances were made with the Statistica computer programme, and the obtained results are summarised in Table 4 . In both tests (see: Table 4) the value of calculated probability for specific
Table 3. Comparison of effectiveness of sewage treatment in medium sand with a supportive small coal layer

\begin{tabular}{lccc}
\hline \multicolumn{1}{c}{$\begin{array}{c}\text { Indicator, } \\
\text { unit }\end{array}$} & $\begin{array}{c}\text { Sand } \\
\text { (Kalenik } \\
\text { and Wancerz, } \\
\text { 2013) }\end{array}$ & $\begin{array}{c}\text { Supportive } \\
\text { layer } \\
\text { consisting of } \\
\text { small coal; } \\
\text { thickness of } \\
0.10 \mathrm{~m}\end{array}$ & $\begin{array}{c}\text { Supportive } \\
\text { layer consisting } \\
\text { of small coal; } \\
\text { thickness of } \\
0.20 \mathrm{~m}\end{array}$ \\
\hline TSS, \% & 80.2 & 51.3 & 71.1 \\
\hline BOD $_{5}, \%$ & 97.8 & 98.7 & 99.8 \\
\hline COD, \% & 87.7 & 90.4 & 95.1 \\
\hline $\begin{array}{l}\text { Total nitrogen, } \\
\%\end{array}$ & 22 & 31.9 & 56.6 \\
\hline $\begin{array}{l}\text { Ammonium } \\
\text { nitrogen, \% }\end{array}$ & 99 & 87.8 & 94.9 \\
\hline $\begin{array}{l}\text { Total } \\
\text { phosphorus, \% }\end{array}$ & 23 & 48.5 & 79.1 \\
\hline
\end{tabular}

Table 4. Results of statistic calculation from Shapiro-Wilk and Leven tests. The differences in the mean values are significant with a probability of $\mathrm{p}>0.05$

\begin{tabular}{|c|c|c|c|}
\hline Parameter & $\begin{array}{c}\text { Thickness } \\
{[\mathrm{m}]}\end{array}$ & $\begin{array}{l}\text { Probability value calculated with } \\
\text { Shapiro-Wilk test } \\
\mathrm{p}_{\text {obl. }}\end{array}$ & $\begin{array}{l}\text { Probability value calculated } \\
\text { with Levene test } \\
\qquad \mathrm{p}_{\text {obl. }}\end{array}$ \\
\hline Total suspended solids & 0.10 & 0.79823 & \multirow{2}{*}{0.7457} \\
\hline Total suspended solids & 0.20 & 0.97188 & \\
\hline $\mathrm{BOD}_{5}$ & 0.10 & 0.97188 & \multirow{2}{*}{0.5060} \\
\hline $\mathrm{BOD}_{5}$ & 0.20 & 0.27245 & \\
\hline COD & 0.10 & 0.98859 & \multirow{2}{*}{0.4973} \\
\hline COD & 0.20 & 0.51304 & \\
\hline Total nitrogen & 0.10 & 0.84997 & \multirow{2}{*}{0.4680} \\
\hline Total nitrogen & 0.20 & 0.79823 & \\
\hline Ammonium nitrogen & 0.10 & 0.27245 & \multirow{2}{*}{1.00} \\
\hline Ammonium nitrogen & 0.20 & 0.27245 & \\
\hline Nitrate nitrogen & 0.10 & 0.92452 & \multirow{2}{*}{0.8675} \\
\hline Nitrate nitrogen & 0.20 & 0.51406 & \\
\hline Nitrite nitrogen & 0.10 & 0.27245 & \multirow{2}{*}{0.1682} \\
\hline Nitrite nitrogen & 0.20 & 0.68296 & \\
\hline Total phosphorus & 0.10 & 0.97007 & \multirow{2}{*}{0.1975} \\
\hline Total phosphorus & 0.20 & 0.57735 & \\
\hline Reaction & 0.10 & 0.71428 & \multirow{2}{*}{1.00} \\
\hline Reaction & 0.20 & 0.71428 & \\
\hline
\end{tabular}


Kalenik, M. (2019). Study of effectiveness of sewage treatment in medium sand with a supportive small coal layer. Acta Sci. Pol., Formatio Circumiectus, 18 (3), 57-70. DOI: http://dx.doi.org/10.15576/ASP.FC/2019.18.3.57

groups was calculated $\mathrm{p}_{\text {obl. }}>0.05$ from the adopted significance level $\alpha=0.05$, which means that the normal distributions and homogeneity of variance in the examined groups were met. Then the Student's t-test for two populations was used, assuming the null hypothesis $\left(\mathrm{H}_{0}: \mathrm{n}_{1}=\mathrm{n}_{2}\right)$ that the differences in mean values are statistically equal, and an alternative one $\left(\mathrm{H}_{1}: \mathrm{n}_{1} \div \mathrm{n}_{2}\right)$ that the differences in mean values are statistically different. Calculation of the $\mathrm{t}_{\mathrm{obl}}$ statistic value (t-Student), was also made using the computer programme Statistica, and the results obtained are summarised in Table 5.

For the alternative hypothesis a critical area $t_{\text {obl. }} \geq$ $\mathrm{t}_{\alpha=0.05}$ was determined and from the tables of the $\mathrm{t}$-Stu- dent's distribution for $\mathrm{v}=\mathrm{n}_{1}+\mathrm{n}_{2}-2=6$ degrees of freedom and $\alpha=0.05$, i.e. the chosen $5 \%$ error risk (significance level), the critical value $\mathrm{t}_{\alpha=0.05}=2.447$ was read. In table 5 we can see that $\left|t_{\text {obl }}\right| \div \mathrm{t}_{\alpha=0.05}$ so the null hypothesis can be rejected and it can be concluded that differences between mean values in the results of the effectiveness of sewage pollution removal for supportive small coal layers with a thickness of $0.10 \mathrm{~m}$ and $0.2 \mathrm{~m}$ are indeed different statistically. This is confirmed also by the counted probability value, and namely $\mathrm{p}_{\mathrm{obl}}$ is lower than $\mathrm{p}<0.05$ (of the adopted significance level).

Table 5. Results of statistic calculation from the Student's t-test. The differences in the mean values are significant with a probability of $\mathrm{p}<0.05$

\begin{tabular}{|c|c|c|c|c|c|c|}
\hline Parameter & $\begin{array}{l}\text { Thickness } \\
{[\mathrm{m}]}\end{array}$ & Average & $\begin{array}{l}\text { Standard } \\
\text { deviation }\end{array}$ & $\begin{array}{c}\text { Calculated value } \\
\text { of the Student's t-test } \\
\qquad\left|t_{\text {obl. }}\right|\end{array}$ & $\begin{array}{c}\text { Calculated } \\
\text { probability value } \\
\mathrm{p}_{\mathrm{obl}}\end{array}$ & $\begin{array}{c}\text { Read value } \\
\text { of the Student's t-test } \\
\text { from tables } \\
\mathrm{p}=0.05 \text { and } \mathrm{v}=6 \\
\mathrm{t}_{\mathrm{a}=0.05}\end{array}$ \\
\hline Total suspended solids & 0.10 & 37.875 & 0.222 & \multirow{2}{*}{103.956} & \multirow{2}{*}{0.00000196} & \multirow{18}{*}{2.447} \\
\hline Total suspended solids & 0.20 & 17.800 & 0.258 & & & \\
\hline $\mathrm{BOD}_{5}$ & 0.10 & 3.750 & 0.129 & \multirow{2}{*}{40.133} & \multirow{2}{*}{0.0000340} & \\
\hline $\mathrm{BOD}_{5}$ & 0.20 & 1.225 & 0.096 & & & \\
\hline COD & 0.10 & 37.525 & 0.506 & \multirow{2}{*}{54.521} & \multirow{2}{*}{0.0000136} & \\
\hline COD & 0.20 & 17.125 & 0.330 & & & \\
\hline Total nitrogen & 0.10 & 23.575 & 0.171 & \multirow{2}{*}{98.727} & \multirow{2}{*}{0.00000229} & \\
\hline Total nitrogen & 0.20 & 15.025 & 0.222 & & & \\
\hline Ammonium nitrogen & 0.10 & 0.228 & 0.0096 & \multirow{2}{*}{18.385} & \multirow{2}{*}{0.000351} & \\
\hline Ammonium nitrogen & 0.20 & 0.098 & 0.0096 & & & \\
\hline Nitrate nitrogen & 0.10 & 16.938 & 0.070 & \multirow{2}{*}{112.621} & \multirow{2}{*}{0.00000154} & \\
\hline Nitrate nitrogen & 0.20 & 11.933 & 0.071 & & & \\
\hline Nitrite nitrogen & 0.10 & 0.0068 & 0.00096 & \multirow{2}{*}{6.928} & \multirow{2}{*}{0.00617} & \\
\hline Nitrite nitrogen & 0.20 & 0.0028 & 0.00050 & & & \\
\hline Total phosphorus & 0.10 & 2.593 & 0.043 & \multirow{2}{*}{79.877} & \multirow{2}{*}{0.00000432} & \\
\hline Total phosphorus & 0.20 & 1.050 & 0.022 & & & \\
\hline Reaction & 0.10 & 7.673 & 0.033 & \multirow{2}{*}{-21.229} & \multirow{2}{*}{0.000229} & \\
\hline Reaction & 0.20 & 8.192 & 0.039 & & & \\
\hline
\end{tabular}




\section{SUMMARY}

Sewage treated in sandy soil beds with a supportive small coal layer with a granulation of $0.02 \div 5 \mathrm{~mm}$ met the Polish requirements concerning the rules of household sewage introduction into ground and groundwaters (Rozporządzenie..., 2019) in terms of basic quality indicators (TSS, BOD5, COD, total nitrogen and total phosphorus). It was determined that a soil bed consisting of medium sand with a supportive layer of small coal with a thickness of $0.20 \mathrm{~m}$ is more effective in sewage treatment in comparison to a supportive layer with a thickness of $0.10 \mathrm{~m}$. Application of the supportive layer of small coal with a thickness of $0.2 \mathrm{~m}$ in the medium sand soil bed improved the removal effectiveness of TSS by an average $19.8 \%, \mathrm{BOD}_{5}$ by $1.1 \%$, COD by $4.7 \%$, total nitrogen by $24.7 \%$, ammonium nitrogen by $7.1 \%$ and total phosphorus by $30.6 \%$ in comparison to a supportive layer with a thickness of $0.10 \mathrm{~m}$.

Small coal with a granulation of $0.02 \div 5 \mathrm{~mm}$ can be used to remove nitrogen and phosphorus compounds from sewage in household sewage treatment plants with the infiltration drainage. Very high effectiveness of TSS removal from sewage in the tested model soil beds may lead to a quick bed colmatation under a sewage infiltration drainage. Consequently, septic tanks should be designed so that they can block as much total suspended solids as possible, e.g. multi-chamber tanks instead single-chamber ones.

\section{REFERENCES}

Beal, C. D., Gardner, E. A., Menzies, N. W. (2005). Process, performance, and pollution potential: A review of septic tank-soil absorption systems. Aust. J. Soil Res., 43(7), 781-802.

Canter, W.L., Knox, R.C. (1991). Septic tank system effects on ground water quality. Lewis Publisher, Inc. Chelsea, Michigan.

Centralny Urząd Gospodarki Wodnej. (1971). Budownictwo oczyszczalni ścieków. Wytyczne techniczne projektowania drenaży rozsączających i filtrów piaskowych. Warszawa: Wyd. Katalogów i Cenników.

Chmielowski, K., Ślizowski, R. (2008). Defining the optima range of a filter bed's $d_{10}$ replacement diameter in vertical flow sand filters. Environ. Prot. Eng., 34(3), $35-42$.
Dacewicz, E. (2018). Application of selective and porous materials for the removal of biogenic compounds and indicator bacteria from domestic wastewater. Acta Sci. Pol. Formatio Circumiectus, 17(2), 47-55.

Eveborn, D., Kong, D., Gustafsson, J.P. (2012). Wastewater treatment by soil infiltration: Long-term phosphorus removal. J. Contam. Hydrol., 140-141(10), 24-33.

Gill, L.W. O’luanaigh, N., Johnston, P.M., Misstear, B.D.R., O'suilleabhain C. (2009). Nutrient loading on subsoils from on-site wastewater effluent, comparing septic tank and secondary treatment systems. Water Res., 43(10), 2739-2749.

Hawkins, C.L., Shipitalo, M.J., Moye Rutledge, E., Savin, M.C., Brye, K.R. (2008). Earthworm populations in septic system filter fields and potential effects on wastewater renovation. Appl. Soil Ecol., 40(1), 195-200.

Heatwole, K.K., Mccray, J.E. (2007). Modeling potential vadose - zone transport of nitrogen from onsite wastewater systems at the development scale. J. Contam. Hydrol., 91(1-2), 184-201.

Kalenik, M. (2014a). Skuteczność oczyszczania ścieków $\mathrm{w}$ gruncie piaszczystym $\mathrm{z}$ warstwą naturalnego klinoptylolitu. Ochr. Sr., 36(3), 43-48.

Kalenik, M. (2014b). Eksperymental investigations of interface valve flow capacity in the RoeVac type vacuum sewage system. Environ. Prot. Eng., 40(3), 127-138, DOI:10.5277/epe140310.

Kalenik, M. (2015). Badania modelowe sprawności powietrznego podnośnika cieczy. Ochr. Sr., 37(4), 39-46.

Kalenik, M. (2017). Badania modelowe strumienia objętości piasku i wody w podnośniku powietrznym. Ochr. Sr., 39 (1), 45-52.

Kalenik, M. (2019). Badania modelowe skuteczności oczyszczania ścieków w piasku średnim $\mathrm{z}$ warstwą wspomagającą z hydro-antracytu. Scientific Review Engineering and Environment Sciences, 28(2), 257-267, DOI: $10.22630 /$ PNIKS.2019.28.2.24.

Kalenik, M., Chalecki, M. (2018). Experimental Study of Air Lift Pump Delivery Rate. Rocz. Ochr. Sr., 20, 221-240.

Kalenik, M., Chalecki, M. (2019). Investigations on the effectiveness of wastewater purification in medium sand with assisting clinoptilolite layer. Environ. Prot. Eng., 45(2), 117-126, DOI: 10.5277/epe190208.

Kalenik, M., Cieśluk, M. (2009). Sewage treatment in gravel with assisting dolomite layer. Sewages and waste materials in environment. Monograph edited by Wiera Sądej. Printing: Warmia and Mazury Center of Agriculture Consulting Service in Olsztyn, Olsztyn. Chapter II, 23-33.

Kalenik, M., Malarski, M. (2018). Performance tests of an airlift pump equipped with a perforated rubber dia- 
phragm mixer. Acta Sci. Pol. Formatio Circumiectus, 17 (1), 19-28. DOI: http://dx.doi.org/10.15576/ASP. FC/2018.17.1.19.

Kalenik, M., Wancerz, M. (2013). Badania oczyszczania ścieków w piasku średnim z warstwą wspomagającą z chalcedonitu - skala laboratoryjna. Infrastruktura i Ekologia Terenów Wiejskich, 3/I, 163-173.

Koda, E., Miszkowska, A., Sieczka, A. (2017). Levels of Organic Pollution Indicators in Groundwater at the Old Landfild and Waste Management Site. Appl. Sci., 7(6), 638-660.

Kołwzan, B., Adamiak, W., Dziubek, A. M. (2018). Możliwości zastosowania grzybów w technologiach oczyszczania i remediacji wybranych elementów środowiska. Ochr. Sr., 40(1), 3-20.

Kvarnström, M.E., Morel, C.A.L., Krogstad, T. (2004). Plant-availability of phosphorus in filter substrates derived from small-scale wastewater treatment systems. Ecol. Eng., 22 (1), 1-15.

Kujawiak, S., Makowska, M., Matz, R. (2018). Hydraulic characteristics of the airlift pump. Acta Sci. Pol. Formatio Circumiectus, 17 (4), 85-95. DOI: http://dx.doi. org/10.15576/ASP.FC/2018.17.4.85

Laak, R. (1986). Wastewater engineering design for unsewered areas. Published by Technomic Publishing Company, Inc. Lancaster - Basel.

Małe oczyszczalnie ścieków. (1990). Ogólne zalecenia 87:6. Szwedzki Urząd Ochrony Przyrody. Ingvar Bingman, Sztokholm.

Mazur, R., Bedla, D., Chmielowski, K., Nowak, A., Mazurkiewicz, J. (2016). Wpływ warunków tlenowych na skuteczność oczyszczania ścieków bytowych w technologii zatapialnych filtrów włókninowych. Przem. Chem., 95 (8), 1513-1517.

Mycielska-Dowgiałło, E., Woronko, B. (1998). Analiza obtoczenia i zmatowienia powierzchni ziaren kwarcowych frakcji piaszczystej i jej wartość interpretacyjna. Przegląd Geologiczny, 46(12), 1275-1281.

Nieć, J., Spychała, M. (2014). Hydraulic conductivity estimation test impact on long-term acceptance rate and soil absorption system design. Water, 6(9 ), 2808-20820; doi:10.3390/w6092808.

PN-C-04616/10. (1987). Woda i ścieki. Badania specjalne osadów. Hodowla standardowego osadu czynnego w warunkach laboratoryjnych. Warszawa: Wyd. Normalizacyjne Alfa.

Radziemska, M., Vaverkowa, M. D., Baryła, A. (2017). Phytostabilization-Management Strategy for Stabilizing Trace Elements in Contaminated Soils. Int. J. Environ. Res. Pub. He., 14(9), 958-973.

Rozporządzenie Ministra Infrastruktury z dnia 12 kwietnia 2002 roku w sprawie warunków technicznych, jakim powinny odpowiadać budynki i ich usytuowanie. (Dz. U. Nr 75, poz. 690).

Rozporządzenie Ministra Gospodarki Morskiej i Żeglugi Śródlądowej z dnia 12 lipca 2019 roku w sprawie substancji szczególnie szkodliwych dla środowiska wodnego oraz warunków, jakie należy spełnić przy wprowadzaniu do wód lub do ziemi ścieków, a także przy odprowadzaniu wód opadowych lub roztopowych do wód lub do urządzeń wodnych (Dz. U. 2019, poz. 1311).

Sieczka, A., Koda, E. (2016a). Identyfikacja parametrów sorpcji związków azotu w środowisku gruntowo-wodnym metodą eksperymentu kolumnowego. Ochr. Sr., 38(3), 29-34.

Sieczka, A., Koda, E. (2016b). Kinetic and Equilibrium Studies of Sorption of Ammonium in the Soil-Water Environment in Agricultural Areas of Central Poland. Appl. Sci., 6(10), 269-283.

Spychała, M. Nieć, J. (2013). Impact of septic tank sludge on filter permeability. Environ. Prot. Eng., 39(2), 77-89, DOI: $10.5277 /$ EPE130208.

Spychała, M., Pilc, L. (2011). Can Earthworms De-Clog Sand Filters? Pol. J. Environ. Stud., 20(4), 1037-1401.

Tymosiak, D., Sulewska, M. J. (2016). Badania parametrów zagęszczalności gruntów niespoistych metodą Proctora. Acta Sci. Pol. Architectura, 15(3), 43-54.

Ustawa z dnia 7 lipca 1994 r. Prawo budowlane (Dz. U. 1994, Nr 89, poz. 414, z późn. zm.).

Van Cuyk, S., Siegrist, R., Logan, A., Masson, S., Fischer, E., Figueroa, L. (2001). Hydraulic and purification behaviors and their infiltrations during wastewater treatment in soil infiltration systems. Water Res., 35(4), 953-965.

Wąsik, E., Chmielowski, K. (2017). Ammonia and indicator bacteria removal from domestic sewage in a vertical flow filter filled with plastic material. Ecol. Eng., 106, 378-384. 


\section{BADANIA SKUTECZNOŚCI OCZYSZCZANIA ŚCIEKÓW W PIASKU ŚREDNIM Z WARSTWĄ WSPOMAGAJĄCA Z MIAŁU WĘGLOWEGO}

\section{ABSTRAKT}

\section{Cel pracy}

Celem badań było sprawdzenie w warunkach laboratoryjnych, czy wprowadzenie do gruntu warstwy wspomagającej z miału węglowego o granulacji $0,02 \div 5 \mathrm{~mm}$ poprawi skuteczność usuwania związków azotu i fosforu ze ścieków bytowych. Przeprowadzone badania dotyczyły warstwy wspomagającej skuteczność oczyszczania ścieków bytowych w przydomowej oczyszczalni pod drenażem rozsączającym.

\section{Materiał i metody}

Badania modelowe oczyszczania ścieków przeprowadzono w złożu z piasku średniego z warstwą wspomagającą z miału węglowego o miąższości 0,10 i $0,20 \mathrm{~m}$. Zawiesiny ogólne oznaczano metodą wagową, $\mathrm{BZT}_{5}$ metodą elektrochemiczną, ChZT metodą miareczkową z dwuchromianem potasu, azot amonowy, azot azotynowy, azot azotanowy oraz azot ogólny i fosfor ogólny oznaczano z zastosowaniem metod kolorymetrycznych, a odczyn metodą elektrometryczną.

\section{Wyniki i wnioski}

Zaobserwowano, że w odniesieniu do podstawowych parametrów jakościowych (zawiesin ogólnych, $\mathrm{BZT}_{5}$, ChZT, azotu ogólnego, fosforu ogólnego), skuteczność oczyszczania ścieków była zgodna z polskimi wytycznymi odprowadzania ścieków do gruntu i wód podziemnych. Stwierdzono, że złoże gruntowe z piasku średniego z warstwą wspomagającą z miału węglowego o miąższości 0,20 m wykazuje większą skuteczność oczyszczania ścieków w porównaniu do warstwy wspomagającej o miąższości $0,10 \mathrm{~m}$. Zastosowanie w złożu gruntowym z piasku średniego warstwy wspomagającej z miału węglowego o miąższości 0,20 m zwiększyło skuteczność usuwania zawiesiny ogólnej średnio o 19,8\%, BZT 5 średnio o 1,1\%, ChZT średnio o 4,7\%, azotu ogólnego o 24,7\%, azotu amonowego średnio o 7,1\% i fosforu ogólnego o 30,6\% w porównaniu do warstwy wspomagającej o miąższości $0,10 \mathrm{~m}$. Badania potwierdziły, że miał węglowy o granulacji $0,02 \div 5 \mathrm{~mm}$ może być stosowany do wspomagania usuwania związków azotu i fosforu ze ścieków z zastosowaniem drenaży rozsączających.

Słowa kluczowe: przydomowa oczyszczalnia ścieków, drenaż rozsączający, miał węglowy 